\title{
GAMBARAN FAKTOR-FAKTOR YANG MEMPENGARUHI KEPATUHAN DIET PENDERITA DIABETES MELLITUS DI WILAYAH PUSKESMAS PAKIS SURABAYA
}

\author{
*Yusti Fauzia, ** Ethyca Sari, ***Budi Artini \\ AKPER William Booth Jln. Cimanuk No. 20 Surabaya, Telp. (031) 5633365
}

\begin{abstract}
ABSTRAK
Keberhasilan pengobatan pada penderita Diabetes Melitus salah satunya ditunjang dari kepatuhan dietnya. Terlaksananya kepatuhan diet ini dipengaruhi oleh faktor usia, jenis kelamin, pendidikan, pekerjaan, pengetahuan, dukungan keluarga, dan dukungan tenaga kesehatan. Keterlibatan faktor-faktor ini akan membuat seorang penderita Diabetes Melitus dapat mempertahankan kondisi kesehatannya. Penderita Diabetes Mellitus sering datang ke Puskesmas dengan kondisi gula darah masih tinggi. Tujuan dari penelitian ini adalah untuk mengidentifikasi faktor-faktor yang mempengaruhi kepatuhan diet penderita Diabetes Mellitus. Desain yang digunakan pada penelitian ini deskriptif. Populasi dari Penelitian ini adalah seluruh penderita Diabetes Mellitus di Puskesmas Pakis. Sampel yang digunakan 30 orang dengan menggunakan teknik consecutive sampling. Data diperoleh dari hasil koesioner, data yang terkumpul ditabulasi dengan tabel distribusi frekwensi dan di konfirmasikan dalam bentuk tabel frekwensi. Dari hasil penelitian ini didapatkan hasil faktor pengetahuan mempengaruhi kepatuhan diet sebesar 29 orang (97,\%), faktor sikap mempengaruhi sebesar 28 orang $(93,3 \%)$, faktor dukungan keluarga mempengaruhi sebesar 30 orang $(100 \%)$. Faktor yang paling mempengaruhi adalah faktor dukungan keluarga sebesar 30 orang $(100 \%)$. Hal ini menunjukkan bahwa peran keluarga sangat besar dalam pelaksanaan kepatuhan diet bagi penderita Diabetes Melitus oleh karena itu diperlukan peningkatan pengetahuan keluarga tentang Diet Diabetes Melitus agar dapat mendukung diet keluarganya yang sakit.
\end{abstract}

Kata Kunci : faktor-faktor yang mempengaruhi kepatuhan, kepatuhan diet, penderita diabetes mellitus

\section{ABSTRACT}

Reatment success in patients with diabetes mellitus one of which is supported from his diet adherence. Dietary compliance implementation is influenced by factors of age, sex, education, occupation, knowledge, family support, and support for health professionals. The involvement of these factors will make a patient with diabetes mellitus can maintain his health condition. Diabetes Mellitus Patients often come to the health center with the condition of the blood sugar is still high. The purpose of this study was to identify the factors that influence dietary compliance with Diabetes Mellitus. Design used in this descriptive study. This study is the population of all patients with Diabetes Mellitus in Pakis health center. The sample used 30 people using consecutive sampling technique. Data obtained from the koesioner, the collected data were tabulated by frequency distribution table and were confirmed in the form of frequency tables. From the results of this study showed knowledge of factors affecting dietary compliance by 29 people (97,\%), factors affecting the attitudes of 28 people (93.3\%), family support influencing factors of 30 people (100\%). The most influential factors is the family support factor of 30 people (100\%). This shows that the family is very big role in the implementation of dietary adherence for patients with Diabetes Mellitus therefore necessary to increase family knowledge about Diabetes Mellitus diet diet in order to support his family is sick.

Keywords: factors affecting adherence, diet adherence, patients with diabetes mellitus 


\section{Pendahuluan}

Kepatuhan adalah kondisi ketika individu atau kelompok berkeinginan untuk patuh, tetapi ada sejumlah faktor yang menghambat kepatuhan terhadap saran tentang kesehatan (Carpenito, 2009). Diabetes Mellitus adalah keadaan hiperglikemi kronik yang disertai berbagai kelainan metabolik akibat gangguan hormonal yang menimbulkan berbagai komplikasi kronik pada mata, ginjal, saraf dan pembuluh darah (Masjoer, 1999), diabetes mellitus klinis adalah suatu sindroma gangguan metabolisme dengan hiperglikemia yang tidak semestinya sebagai akibat suatu defisiensi sekresi insulin (Francis, 2000). Ada beberapa faktor-faktor yang menjadikan penyebab dari diabetes mellitus diantaranya faktor keturunan dari seseorang yang mengidap penyakit diabetes mellitus tidak mengatur jadwal control kepusat kesehatan masyarakat, selalu memakan-makanan manis yang tidak terkontrol. Salah satu faktor yang penting dalam menyikapi penyakit diabetes mellitus pada seseorang adalah faktor kepatuhan. Menurut (Niven , 2002) Kepatuhan adalah sejauh mana perilaku pasien sesuai dengan ketentuan yang diberikan oleh tenaga kesehatan. Ada beberapa yang bisa mempengaruhi kepatuhan meliputi faktor internal diantaranya pengetahuan, dukungan keluarga, dukungan sosial. Dilihat dari kenyataan dilapangan bahwa penderita Diabetes Mellitus sering datang ke Puskesmas dengan keluhan mata kabur, badan terasa gatal, sering terbangun dan kencing sering pada malam hari, dengan Berat badan turun sedangkan konsumsi makanan banyak. Padahal mereka yang datang ke Puskesmas mayoritas penderita diabetes mellitus cukup lama ( \pm 1 tahun $)$ petugas puskesmas menanyakan tentang makanan apa yang sudah dikonsumsi sehingga sampai selalu muncul kembali. Biasanya seseorang yang menderita penyakit DM memiliki kekambuhan pada penderita diabetes mellitus yang datang ke pusat pelayanan kesehatan mengalami kekambuhan seperti keluar keringat dingin,kulit gatal dll.

Berdasarkan studi pendahuluan yang dilakukan oleh peneliti di Puskesmas Pakis didapatkan 20 orang yang menderita penyakit Diabetes Mellitus, Dari hasil wawancara 15 orang tahu tentang diet untuk Diabetes Mellitus tetapi mereka ada yang jenuh, ingin mencoba makanan yang enak, ada yang mengatakan tidak bisa menghilangkan ngemil, dan menurut mereka sudah memodifikasi dengan jamu tradisional supaya tidak naik gulanya sehingga mereka bisa makan sembarangan, sedangkan yang 5 orang mengatakan sudah biasa dengan diet yang diberikan sehingga mereka tidak menganggap ini menjadi beban tapi demi kesembuhan mereka. Hubungan Kepatuhan Pola Diet Penderita Diabetes Melitus Tipe II dengan Kadar Gula Darah Sewaktu di Pos Pembinaan Terpadu (POSBINDU) Desa Selokerto Kecamatan Sempor Di Indonesia Diabetes Melitus menempati urutan keenam proporsi penyebab kematian semua umur. Selain olahraga dan terapi, kepatuhan pola diet dan memantau kadar glukosa darah sewaktu pada penderita Diabetes Melitus memberikan alternatif pilihan yang mungkin dapat mencegah terjadinya komplikasi pada penderita Diabetes Melitus Tipe. Tujuan: Penelitian ini bertujuan untuk mengetahui hubungan kepatuhan pola diet penderita Diabetes Melitus Tipe II dengan kadar gula darah sewaktu di Pos Pembinaan Terpadu (POSBINDU) Desa Selokerto Kecamatan Sempor. 0.02. Data yang didapatkan dari Dinas Kesehatan Jawa Timur diperoleh sebanyak 5.551 orang. Dari jumlah tersebut, sebanyak 172 di antaranya meninggal dunia. Dikarenakan karena banyak orang yang tidak patuh pada program diet yang dilakukan sehingga glukosa darah meningkat hingga menimbulkan kematian, sedangkan dipuskesmas diperoleh sebanyak Kebanyakan penderita berusia 40 tahun hingga 50 tahun.

Pada Diabetes Mellitus dapat terjadi karena beberapa faktor, diantaranya adalah faktor herediter yaitu karena adanya kerentanan sel-sel beta terhadap penghancuran oleh virus atau mempermudah perkembangan antibodi autoimun yang melawan sel-sel beta, selain itu ada juga dari faktor imunologi dimana respons autoimun yang merupakan respons abnormal, sehingga antibodi terarah pada jaringan normal tubuh dengan cara bereaksi terhadap jaringan tersebut, jadi pada intinya penyakit diabetes mellitus bekerja dari insulin di dalam tubuh yang tidak lancar dan dapat menimbulkan penurunan kadar gula seseorang menjadi menurun, Pengetahuan seseorang yang menderita Diabetes Mellitus itu sangat penting apalagi didalam pemahaman mereka terhadap diet yang harus mereka taati. Faktor-faktor yang mempengaruhi kepatuhan 
yaitu interna dan ekterna interna meliputi pengetahuan dan sikap sedangkan pada ekternal meliputi dukungan keluarga dan dukungan tenaga kesehatan Penderita diabetes mellitus apabila tidak menjalankan dietnya dengan baik (tidak patuh) maka yang terjadi penurunan dan peningkatan gula darah yang tidak stabil, selain itu dampak yang lebih parah bisa terjadinya shock hipoglikemi suatu keadaan dimana kadar gula darah hingga dibawah $60 \mathrm{mg} / \mathrm{d}$ atau hiperglikemi kondisi gula darah yang tinggi. atau bisa juga sampai terjadi kematian dampak yang diakibatkan diabetes mellitus bisa terjadi gagal ginjal kronik sehingga ginjal bekerja keras untuk memproduksi urine yang keluar terus menerus. Ketidak patuhan diabetes mellitus terhadap diet dapat berdsampak negative terhadap kesehatannya. Jika makanan yang dikonsumsi tidak dikontrol, komplikasi-komplikasi diabetes melitius yang timbul misalnya pada mata, jantung, saraf dan dapat terjadi komplikasi yang akut seperti hipoglikemi dan ketoasidosis Diabetikum (KAD) dimana jika tidak segera ditangani komplikasi tersebut dapat membahayakan klien.

Melihat permasalahan tersebut diatas maka salah satu cara yang bisa dilakukan untuk memotivasi penderita diabetes mellitus dalam menjalankan dietnya dengan baik adalah memberikan suatu informasi baik melalui komunikasi, edukasi atau penyuluhan kesehatan (KIE) di Puskesmas tentang atau institusi kesehatan dengan pemberian leaflet dan brosur, selain juga pendekatan yang dilakukan oleh petugas kesehatan kepada penderita Diabetes Mellitus sangat penting melalui kunjungan rumah. Guna membantu kepatuhan diet oleh karena itu peneliti tertarik serta membantu keluarga untuk mengambil penelitian ini dengan tujuan untuk mengetahui sejauh mana gambaran faktor-faktor yang mempengaruhi kepatuhan diet pada penderita Diabetes Mellitus di Pusksmas Pakis Surabaya. Adanya efek yang membahayakan terebut maka diperlukan adanya strategi pelaksanaan, dokter dan ahli gizi serta tindakan mandiri perawat seperti memantau makanan yang dikonsumsi, motivasi klien untuk mematuhi diet dan memberikan penyuluhan tentang pentingnya mematuhi diet. Dengan diberikannya penyuluhan diharapkan klien dapat mengetahui cara pengolahan diet dengan benar dan dapat menghindari konsumsi makanan yang berlemak dan manis-manis dengan demikian dapat menurunkan lemak dan mencapai kadar gula dalam batas normal dan untuk klien dianjurkan untuk rutin kontrol dan mengikuti olah raga diabetes dan pembnerian penyuluhan kepada keluarga agar keluarga turut mendukung program diet penderita.

\section{Metode}

Desain penelitian yang digunakan adalah deskriptif yaitu untuk menggambarkan faktor-faktor yang mempengaruhi kepatuhan diet penderita Diabetes Mellitus di wilayah Puskesmas Pakis. Variabel yang digunakan dalam penelitian ini adalah variabel tunggal yaitu gambaran faktor - faktor yang mempengaruhi kepatuhan diet penderita Diabetes Mellitus.

Populasi dalam penelitian ini adalah seluruh penderita DM yang bertempat tinggal di wilayah Puskesmas Pakis Surabaya berjumlah 30 orang. Sampelnya adalah sebagian penderita Diabets Mellitus di wilayah Puskesmas Pakis Surabaya yang memenuhi kriteria penelitian.

\section{Hasil}

\section{Data Umum}

Data umum ini menggambarkan tentang karateristik responden berdasarkan data demografi yang diperoleh melalui kuisioner berdasarkan umur, pekerjaan, dan jenis kelamin.

Karateristik responden berdasarkan usia

Tabel 1 Karakteristik responden berdasarkan usia pada penderita yang mempunyai DM di wilayah Puskesmas Pakis Juni 2013

\begin{tabular}{cccc}
\hline No. & Usia & Jumlah & Prosentase \\
\hline 1 & $\leq 20$ & - & $0 \%$ \\
2 & $21-40$ & 7 & $23,3 \%$ \\
3 & $41-60$ & 22 & $73,4 \%$ \\
4 & $>60$ & 1 & $3,3 \%$ \\
& Jumlah & 30 & $100 \%$ \\
\hline
\end{tabular}

Berdasarkan tabel 1 karateristik responden berdasarkan usia, yang paling banyak berusia $41-60$ tahun yaitu 22 orang $(73,4 \%)$. kelamin
Karakteristik responden berdasarkan jenis 
Tabel 2 Karateristik responden berdasarkan jenis kelamin pada penderita yang mempunyai DM di wilayah Puskesmas Pakis Surabaya Juni 2013

\begin{tabular}{cccc}
\hline No. & Jenis & Jumlah & Prosentase \\
& Kelamin & & \\
\hline 1 & Laki-laki & 4 & $13,3 \%$ \\
2 & Perempuan & 26 & $86,7 \%$ \\
& Jumlah & 30 & 100 \\
\hline
\end{tabular}

Berdasarkan tabel 2 karateristik responden berdasarkan jenis kelamin, yang paling banyak adalah Perempuan yaitu 26 orang $(86,7 \%)$.

Karateristik responden berdasarkan pendidikan Tabel 3 Karateristik responden berdasarkan Pendidikan pada penderita yang mempunyai DM di wilayah Puskesmas Pakis Juni 2013

\begin{tabular}{cccc}
\hline No. & Pendidikan & Jumlah & Prosentase \\
\hline 1 & SD & 0 & 0 \\
2 & SMP & 9 & $30 \%$ \\
3 & SMA & 20 & $66,7 \%$ \\
4 & Perguruan & 1 & $3,3 \%$ \\
& Tinggi & & \\
\hline
\end{tabular}

Berdasarkan tabel 3 karateristik responden berdasarkan pendidikan yang paling banyak adalah SMA 20 orang $(66,7 \%)$.

Karateristik responden berdasarkan pekerjaan Tabel 4 Karateristik responden berdasarkan pekerjaan dipukesmas Pakis Juni 2013

\begin{tabular}{cccc}
\hline No. & Pekerjaan & Jumlah & Prosentase \\
\hline 1 & IRT & 21 & $70 \%$ \\
2 & Swasta & 7 & $23.3, \%$ \\
3 & Wiraswasta & 1 & $3,3 \%$ \\
4 & Perguruan & 1 & $3,3 \%$ \\
& Tinggi & & \\
\hline
\end{tabular}

Berdasarkan tabel 4 karateristik responden berdasarkan pekerjaan yang paling banyak adalah IRT 21 orang $(70 \%)$.

Data Khusus

Karateristik Responden Berdasarkan Faktor Pengetahuan

Tabel 5 Karateristik responden berdasarkan faktor pengetahuan di Puskesmas Pakis Surabaya Juni 2013

\begin{tabular}{ccc}
\hline No. & Faktor Pengetahuan & Prosentase \\
\hline 1 & Mempengaruhi & $96,7 \%$ \\
2 & Tidak & $3,3 \%$ \\
\hline
\end{tabular}

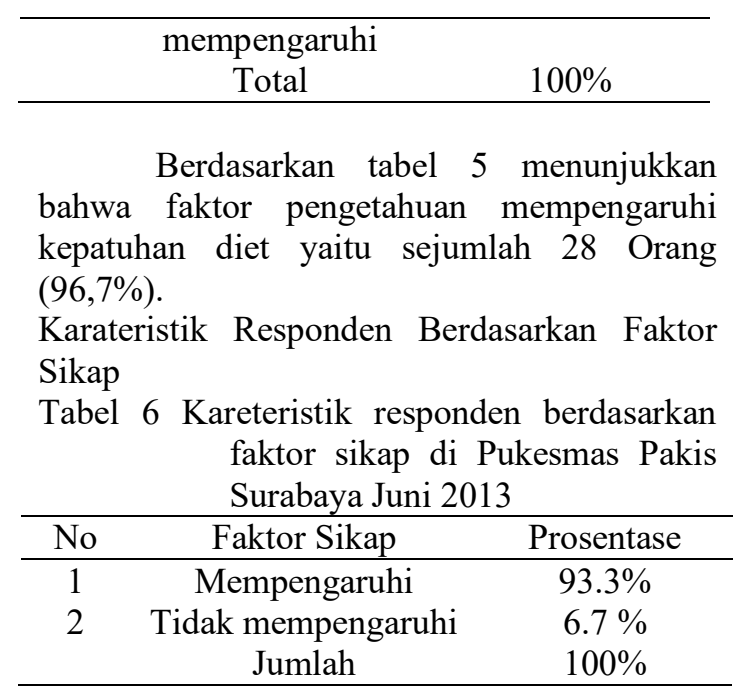

Berdasarkan tabel 6 menunjukkan bahwa bahwa faktor sikap mempengaruhi kepatuhan diet yaitu sejumlah 28 Orang $(96,7 \%)$.

Karateristik Responden Berdasarkan Faktor Dukungan Keluarga

Tabel 7 Karateristik respon berdasarkan faktor dukungan keluarga di Pukesmas Pakis surabaya Juni 2013

\begin{tabular}{ccc}
\hline No & Faktor dukungan keluarga & Prosentase \\
\hline 1 & Mempengaruhi & $100 \%$ \\
2 & Tidak mempengaruhi & $0 \%$ \\
& Jumlah & $100 \%$ \\
\hline
\end{tabular}

Berdasarkan tabel 7 menunjukkan bahwa faktor dukungan keluarga mempengaruhi kepatuhan diet yaitu sejumlah 30 Orang (100\%).

Karateristik Responden Berdasarkan Faktor Dukungan Tenaga Kesehatan

Tabel 8 Karateristik responden berdasarkan faktor dukungan tenaga kesehatan di Pukesmas Pakis Surabaya Juni 2013.

\begin{tabular}{ccc}
\hline No & $\begin{array}{c}\text { Faktor dukungan tenaga } \\
\text { kesehatan }\end{array}$ & Prosentase \\
\hline 1 & Mempengaruhi & $93.3 \%$ \\
2 & Tidak mempengaruhi & $6.7 \%$ \\
3 & Jumlah & $100 \%$ \\
\hline
\end{tabular}

Berdasarkan tabel 8 menunjukkan bahwa faktor dukungan tenaga kesehatan 
mempengaruhi kepatuhan diet yaitu sejumlah 28 Orang $(93.3 \%)$.

Karateristik Responden Berdasarkan Faktor Kepatuhan Diet Penderita DM

Tabel.9 Karateristik responden berdasarkan faktor kepatuhan diet di Pukesmas Pakis Surabaya Juni 2013

\begin{tabular}{cccc}
\hline No & Faktor & $\begin{array}{c}\text { Mempengaru } \\
\text { hi }\end{array}$ & $\begin{array}{c}\text { Tidak } \\
\text { Mempengaru }\end{array}$ \\
\hline 1 & Pengetahuan & $97 \%$ & $3 \%$ \\
2 & Sikap & $93.3 \%$ & $6,7 \%$ \\
3 & Dukungan & $100 \%$ & 0 \\
& Keluarga & & \\
4 & Dukungan & $43,3 \%$ & $6,7 \%$ \\
& Tenaga & & \\
& Kesehatan & & \\
\hline
\end{tabular}

Berdasarkan tabel 9 menunjukkan bahwa dari keempat faktor yang mempengaruhi kepatuhan diet dukungan keluarga adalah faktor yang sangat mempengaruhi kepatuhan diet yaitu sejumlah 30 Orang (100\%).

\section{Pembahasan}

Pada pembahasan ini akan diuraikan dari hasil penelitian mengenai faktor-faktor yang mempengaruhi kepatuhan diet penderita DM di Pukesmas Pakis Surabaya. Berdasarkan tabel 4.9 menunjukkan bahwa faktor pengetahuan, faktor sikap, faktor dukungan keluarga dan dukungan tenaga kesehatan mempengaruhi kepatuhan diet.

Menurut Notoatmodjo (2003)

kepatuhan diet penderita DM dapat dipengaruhi dari faktor pengetahuan, sikap, dukungan keluarga dan dukungan tenaga kesehatan.

\section{Faktor Pengetahuan}

Berdasarkan tabel 4.5 menunjukkan bahwa faktor pengetahuan mempengaruhi kepatuhan diet yaitu sejumlah 28 Orang (96,7\%). Menurut Winkle (1996) semakin cukup umur kematangan dan kekuatan seseorang akan lebih matang untuk berpikir dan bertindak. Apabila dilihat dari tabel 1 karakteristik responden menurut usia didapatkan yang paling banyak yaitu berusia 41-60 tahun yaitu sebnyak 22 orang $(73,4 \%)$ hal ini menunjukkan antara teori dan fakta terdapat kesamaan, semakin bertambahnya usia seseorang maka orang tersebut semakin mampu untuk berpikir dan mempersepsikan informasi yang didapat, sehingga ia akan berusaha untuk mematuhi segala sesuatu yang telah disampaikan untuk dilakukannya. Jika dilihat dari tingkat pendidikan berdasarkan tabel 2 karakteristik responden yang paling banyak yaitu 20 orang dengan tingkat pendidikan SMA . Menurut Nursalam ( 2001) semakin tinggi tingkat pendidikan seseorang maktamlatemakin mudah orang tersebut menerima informasi, sehingga banyak pula pengeandan yang dimiliki. Meskipun dengan tingkaogrendidikan menengah memungkinkan sesebo19 memiliki pengetahuan yang baik karena informasi selain diperoleh dari pendidjkan formal juga bisa diperoleh dari pendidikan non formal ataupun informasi yang didapat dari media massa maupun media elektronik.

\section{Faktor Sikap}

Berdasarkan tabel 6 menunjukkan bahwa bahwa faktor sikap mempengaruhi kepatuhan diet yaitu sejumlah 28 Orang (96,7\%). Menurut Niven (2002) Sikap individu terhadap program pengobatan dipengaruhi oleh tingkat pengetahuan individu sendiri. Semakin tinggi tingkat pengetahuan, maka sikap individu semakin terbuka dengan penatalaksanaan penyakit yang sedang diderita. Hal ini menunjukkan kesamaan antara teori dan hasil penelitian, jika dilihat dari tingkat pendidikan dan usia responden yaitu di usia yang matang dan tingkat pendidikan menengah mendorong mereka untuk terbuka dalam menerima informasi membuat pengetahuan mereka baik sehingga berusaha menerapkannya, dengan sikap tersebut dapat ditunjukan dengan mematuhi program pengobatan yang telah ditetapkan oleh tenaga kesehatan karena penderita penyakit diabetes mellitus diusia dewasa lebih dapat menerima dan mengerti pemasukan dari tenaga kesehatan misalnya harus makan sesuai diet yang diberikan oleh dokter.

Faktor Dukungan Keluarga

Berdasarkan tabel 7 menunjukkan

bahwa faktor dukungan keluarga mempengaruhi kepatuhan diet yaitu sejumlah 30 Orang (100\%). Menurut Niven (2002) Keluarga memberikan perawatan kesehatan yang bersifat prefentif dan secara bersamasama merawat anggota keluarga yang sakit karena keluarga merupakan unit terkecil dari masyarakat yang paling dekat hubungannya 
dengan penderita. Dengan adanya dukungan keluarga dapat meningkatkan kepatuhan penderita dalam penatalaksanaan diet. Hal ini menunjukan bahwa hasil penelitian sesuai dengan teori yang ada. Keluarga merupakan orang yang paling dekat dengan penderita Diabetes Melitus sehingga memungkinkan mereka untuk memantau dan mengingatkan setiap saat mengenai program pengobatan yang harus dilakukan oleh penderita tersebut.

Faktor Dukungan Tenaga Kesehatan Berdasarkan tabel 8 menunjukkan bahwa faktor dukungan tenaga kesehatan mempengaruhi kepatuhan diet yaitu sejumlah 28 Orang (93.3\%). Niven (2002) mengatakan dukungan tenaga kesehatan sangat diperlukan untuk meningkatkan kepatuhan, misalnya yang paling sederhana dalam hal dukungan tersebut adalah dengan adanya teknik komunikasi. Hal ini menunjukkan hasil penelitian sesuai dengan teori yang ada, tenaga kesehatan merupakan orang pertama yang mengetahuai tentang kondisi kesehatan pasien sehingga mereka memiliki peran yang besar untuk menyampaikan informasi mengenai kondisi kesehatan dan hal-hal yang harus dilakukan oleh pasien untuk proses kesembuhannya. Komunikasi ini bisa dilakukan melalui pendidikan kesehatan berupa penyuluhan.

Faktor Dominan yang Mempengaruhi Kepatuhan Diet

Berdasarkan tabel 9 menunjukkan bahwa dari keempat faktor yang mempengaruhi kepatuhan diet dukungan keluarga adalah faktor yang sangat mempengaruhi kepatuhan diet yaitu sejumlah 30 Orang (100\%). Menurut Slamet Suyono (1999), menyatakan bahwa dukungan dari orang sekitar dapat mendidik masyarakat agar menjalani hidup sehat dan menghindari cara hidup yang beresiko. Dukungan keluarga khususnya pada klien DM sangat penting hal ini dikarenakan pemberian pengobatan dan penatalaksanaan diet dilakukan seumur hidup, seseorang yang terkena DM ini akan mengalami kejenuhan atau kebosanan dan mengkonsumsi baik itu makanan, pengobatan ataupun cara hidup, apabila tidak ada dukungan dari orang terdekat maka yang terjadi orang tersebut akan mengalami kondisi stress, apabila stress ini dibiarkan maka akan memperburuk kondisi individu ini sehingga penyakita diderita semakin parah.

\section{Simpulan}

Berdasarkan dari hasil penelitian dengan judul Gambaran Faktor - Faktor Yang Mempengaruhi Kepatuhan Diet Penderita Diabetes Mellitus yang diambil dari 30 responden bahwa faktor yang berpengaruh adalah faktor pengetahuan $96 \%$ sebanyak 29 orang, faktor sikap $93 \%$ sebanyak 28 orang faktor dukungan keluarga (100\%) sebanyak 30 orang faktor dukungan tenaga kesehatan 93\% sebanyak 28 orang.

Saran

Bagi Puskesmas Pakis Suarabaya

Dapat lebih meningkatkan pemberian informasi kesehatan melalui penyuluhan tentang diet dampak dari tidak patuh penderita akan mengalami komplikasi mata, neurologi.

Bagi Institusi Pendidikan

Diharapkan penelitian ini menjadi alat informasi untuk mengembangkan ilmu keperawatan dan menambah perbendaharaan yang ada diperpustakaan AKPER William Booth Surabaya.

Bagi peneliti selanjutnya

Diharapkan penelitian ini dapat menjadi acuan bagi penelitiselanjutnya dalam mengembangkan peneliti yang lain dan dapat menggal lebih dalam tentang ilmu penyakit dalam khususnya tentang penyakit diabetes mellitus

\section{Daftar Pustaka}

Almatsier, Sunita. 2010. Penuntun Diet. Cet. 25. Jakarta :Kompas Gramedia

Arikunto, Suharsimi. 1998. Prosedur Penelitian. Jakarta : Rineka Cipta

Azwar, S. 1998. Metode Penelitian Jakarta : EGC

Brunner and Suddarth, 2000, Keperawatan Medikal Bedah, Jakarta : EGC

Carpenito, Lynda Juall, 1999, Diagnosa Keperawatan Aplikasi pada Praktek Klinik Edisi 8, Jakarta

Fajri, Em dkk, 2000, Kamus Lengkap Bahasa Indonesia. Jakarta

Masyhuri, \& Zainuddin, M. 2008. Metodologi Penelitian Pendekatan Praktis dan Aplikatif. Bandung..

Notoatmodjo, S .2003. Metodologi Penelitian Kesehatan. Jakarta : PT Rineka Cipta.

Nursalam, Siti Pariani, 2001. Pendekatan Praktis Metodelogi Riset 
Keperawatan. Jakarta : Salemba Medika

—, Soekidjo. 2005. Metodologi Penelitian Kesehatan. Jakarta :RinekaCipta.

Nursalam. 2003. Metode Riset Keperawatan. Jakarta :Salemba Medika.

, 2008. Konsep Dan Penerapan Metodologi Penelitian Ilmu Keperawatan Riset Edisi 2 Jakarta : Salemba Medika.

Pamela. J. Brink, Marylin J. Wood. Langkah Dasar Dalam Perencanaan Riset Keperawatan. Jakarta: EGC.

Setiadi. 2007. Konsep\&Penulisan Riset Keperawatan. Yogyakarta :Garahllmu.

Tjokroprawiro. Askandar, 2000, Diabetes Mellitus Klasifikasi, Diagnosa dan Terapi, Jakarta : Gramedia Pustaka Utama 